\title{
ASPECTS OF THE FUSION OF CELLS IN VITRO WITHOUT VIRUSES
}

\author{
J. A. LUGY \\ Department of Biochemistry and Chemistry, Royal Free Hospital School of Medicine, \\ University of London, London WC1N $1 B P$
}

\section{INTRODUCTION}

My colleagues and I are investigating a number of problems relating to the fusion of somatic cells, and I shall therefore be concerned primarily with this theme in the present paper.

It has been known for some years that mammalian cells occasionally fuse spontaneously in tissue culture. More amenable to experimental study, however, is the relatively frequent cell fusion that results after treatment of a wide variety of cells with specific viruses, in particular the Sendai virus. Many investigators have used virus-induced cell fusion as a valuable experimental tool in cell biology and others have studied its mechanisms. Despite this, the biochemical basis of virus-induced fusion remains unknown. It is nevertheless interesting in the context of this Symposium, and of the need for capacitation of a spermatozoon to be completed before the acrosome reaction can occur, to note a recent observation that has been made by Homma \& Tamagawa (1973) concerning the fusogenic properties of Sendai virus. When this virus is grown in mouse fibroblasts ( $L$ cells) instead of in hen eggs, it loses its ability to induce cell fusion after only one passage in L cells. It also loses its haemolytic properties and its infectivity for L cells. Homma \& Tamagawa (1973) have found that trypsin treatment of the virus from $\mathrm{L}$ cells simultaneously restores its fusogenic properties, ability to haemolyse cells, and infectivity, all of which appear to become masked when the virus is grown in $\mathrm{L}$ cells. This phenomenon is clearly relevant to the idea that capacitation of spermatozoa may involve the unmasking of receptor sites on membranes in order to allow the plasma membrane of the sperm cell to fuse with its outer acrosomal membrane in the acrosome reaction.

A new way of fusing mammalian somatic cells is by the technique of 'microsurgery' that has been developed in the U.S.A. (Diacumakos \& Tatum, 1972; Diacumakos, 1973). This procedure involves the impaling with a microneedle of two cells that are in close contact: these cells then fuse. Cell fusion induced by microsurgery is reported not to be dependent on $\mathrm{pH}$ or temperature. An interesting aspect of the technique is that it can be applied only to pairs of cells in telophase, and three individual cells arise-the fused cell, and one unfused cell from each of the telophase pairs. Here then is another instance, which may also be of some relevance to fertilization, of the 'conditioning' of membrane systems before fusion proceeds. 


\section{STABILITY AND INSTABILITY IN GELL MEMBRANES}

On thermodynamic grounds it has been suggested by Danielli (1967) that the lipid bilayer is a natural unit of structure in the same sense that the $\alpha$ helix and the double-stranded helix of DNA are natural units. Furthermore, the properties of two important experimental models for biological membranes, namely the lipid bilayer initially studied by Mueller, Rudin, Tien \& Wescott (1964) and extensively reviewed by Goldup, Ohki \& Danielli (1970), and the liposome model introduced by Bangham (see Bangham, 1968) that has been the subject of a recent monograph by Papahedjopoulos \& Kimelberg (1973), also lend considerable support to the concept that lipid bilayers provide the basic structure for natural membranes. Hence, although the recent model in which a membrane is thought of as a two-dimensional, orientated, viscous solution of amphipathic proteins that float like icebergs in a 'sea' of lipid bilayer (Singer \& Nicolson, 1972) it differs quite markedly from that proposed much earlier by Danielli \& Davson (1934-35), the lipid bilayer is a major feature of both models.

Numerous writers have drawn attention to the inherent stability of the bimolecular lipid sheet in relation to the properties of biological membranes. Bangham (1963) commented that this arrangement of molecules has many virtues, for not only does it give impermeable barriers with great economy of material, but it can also provide quasi-catalytic surfaces for the activation of chemical or enzymatic reactions. However, even though the formation of living creatures may initially have been dependent on the barrier properties of phospholipid membranes which sequestered small droplets of biochemical soup away from the primeval sea, the development of complex life forms would seem to have relied no less on the ability of phospholipid membranes to fuse. Without membrane fusion, fertilization could not occur. More specifically, there would be no acrosome reaction, union between sperm and egg, or release of the contents of the cortical granules from the egg to help protect it from polyspermy. These ambivalent properties of membranes indicate, as suggested above, that inherently stable bilayer membranes need to be 'conditioned' before they can fuse. The conditioning process presumably involves the introduction of a sufficient measure of instability into the bilayer to allow membrane fusion to occur. On the other hand, this instability must be closely controlled and not allowed to become excessive, otherwise a complete breakdown of membrane structure and function will result.

I am concerned in this paper with some of the ways in which biological membranes may be conditioned in order to allow them to fuse. Only those factors that are relevant to the mechanisms of cell fusion that have been studied in my laboratory are discussed at any length, however, and it should be appreciated that other possible mechanisms and considerations may be at least equally important. For example, the presence of calcium ions is almost a sine qua non in membrane fusion. The precise function or functions of calcium are not known, but its importance has led Poste \& Allison $(1971,1973)$ to put forward a general hypothesis for membrane fusion that embodies the activity of a calcium-dependent ATPase. 


\section{LYCOLEGITHIN AND GELL FUSION}

One way in which membranes may be conditioned or reduced in stability in favour of fusion involves the transient presence of lysolecithin, which is a highly fusogenic substance (see below).

Lysolecithin is formed from lecithin by a hydrolytic reaction that is catalysed by phospholipase A-type enzymes, some of which are attached to membranes in vivo. Membrane-bound phospholipase A enzymes are quite widely distributed in cells, in mitochondria (Waite, Van Deenen, Ruigrok \& Elbers, 1969), endoplasmic reticulum (Bjørnstad, 1966), and plasma membranes (Newkirk \& Waite, 1971); membrane-bound phospholipases also occur in lysosomes (Rahman, Verhagen \& Wiel, 1970; Nachbaur, Golbeau \& Vignais, 1972). Since similarities exist between lysosomes and acrosomes (Dott, 1969), the idea that lysolecithin may be involved in membrane fusion occurring during the acrosome reaction would appear to deserve some consideration, especially as lysolecithin may subsequently be removed again by, for example, reacylation to lecithin (Mulder, Van den Berg \& Van Deenen, 1965). The degradative and regenerating reactions, producing and removing lysolecithin, provide a potential control system whereby the structures of membranes may be changed to allow fusion to occur as necessary, and a number of varied instances in which lysolecithin may be involved in membrane fusion have been documented previously (Poole, Howell \& Lucy, 1970).

Suzuki \& Matsumoto (1974) have reported that a release of lysosomal acid phospholipases to the cytosol occurs in cultured human amnion cells on infection with measles virus, which almost parallels the pathological formation of multinucleated giant cells by fusion. By contrast, it has been observed that lysolecithin inhibits the fusion of myoblasts in vitro, and that subsequent removal of lysolecithin allows cell fusion to occur (Reporter \& Norris, 1973). Attention also needs to be drawn to a number of negative results in experiments designed to investigate the possible involvement of lysolecithin in virus-induced cell fusion (Falke, Schiefer \& Stoffel, 1967; Elsbach, Holmes \& Choppin, 1969; Blough, Gallaher \& Weinstein, 1973; Pasternak \& Micklem, 1974), but as Pasternak \& Micklem have noted the number of molecules of lysolecithin concerned may be rather small. Although they estimated that any lysolecithin produced in their experiments during fusion induced by Sendai virus corresponded to an intracellular concentration of less than $100 \mu \mathrm{M}$, this should therefore be compared with values of approximately $20 \mu \mathrm{M}$ external lysolecithin (Ahkong, Cramp, Fisher, Howell \& Lucy, 1972) or approximately 100 to $400 \mu \mathrm{M}$ other lipids (Ahkong, Fisher, Tampion \& Lucy, 1973a) that are sufficient to cause fusion of various cell types. In any case if deacylation by phospholipase $\mathrm{A}$ is rapidly followed by reacylation, local fluctuations of lysolecithin might escape detection. Alternatively, should the lysolecithin be derived from the virus (see Barbanti-Brodano, Possati \& LaPlaca, 1971), there would be no conflict with the results of Pasternak \& Micklem (1974). It has been pointed out elsewhere (Lucy, 1974) that, in view of the rapidity and severity of the damage to membrane systems which is often induced by lysolecithin itself, other lysophospholipids might be more suitable candidates as biological mediators of membrane fusion. It is interesting 
to note then that lysophosphatidylethanolamine produces the most remarkable shape changes in rat erythrocytes, and that the sequence of membrane transformations produced by lysophosphatides in vitro could satisfactorily explain most of the age-dependent changes found with red blood cells in vivo (Rahman, Wright \& Cerny, 1973).

A new factor has recently emerged. Lysolecithin added exogenously to erythrocytes is haemolytic, but lysolecithin formed in situ from membrane lecithin by the action of phospholipase $A_{2}$ from bee venom is surprisingly not, even though the enzyme extensively degrades the phospholipids of the erythrocyte membranes (Zwaal, Roelofsen \& Colley, 1973). In our laboratory, a purified preparation of the enzyme (Shipolini \& co-authors, 1971), kindly provided by Professor G. A. Vernon, has also been found to be totally without effect as a fusogen. In these experiments hen erythrocytes (approx. $8 \times 10^{8}$ cells) were incubated at $37^{\circ} \mathrm{C}$ in $2 \mathrm{ml}$ of a modified Eagle's basal salt solution buffered at $\mathrm{pH} 7.4$ (Ahkong et al., 1973a) with $10 \mu \mathrm{g}$ of the enzyme for $2 \mathrm{hr}$. Thin-layer chromatography of the extracted membrane lipids showed that appreciable hydrolysis had occurred with the formation of fatty acids and lysophospholipids. Despite the hydrolysis, haemolysis of the cells was less than $5 \%$ and no cell fusion was observed. After incubation for $5 \mathrm{hr}$ the cells had lysed but had not fused. Similarly, endogenous lysolecithin, unlike the molecule added exogenously, causes neither rapid lysis or fusion of human erythrocytes. Thus, if lysolecithin has a fusogenic role in vivo, it may need to be exogenously inserted into membranes. Alternatively, the lysophospholipid may conceivably function in combination with one or more proteins that have properties resembling those of 'Iytic factors' in snake venoms (Condrea, 1974).

In view of these numerous complications, what are the reasons for thinking that lysolecithin may be fusogenic in vivo? The justification for considering this lies in experimental observations that lysolecithin, under appropriate conditions, can induce membranes to fuse in vitro. Initially, it was proposed on theoretical grounds that lysolecithin might cause membrane fusion (Lucy, 1969), and subsequently it was shown that hen erythrocytes fuse into multinucleated syncytia within $30 \mathrm{sec}$ of contact with lysolecithin dissolved in aqueous buffer (Howell \& Lucy, 1969). Later we found that the action of lysolecithin is not restricted to hen erythrocytes, and that heterokaryons could be formed by fusing mouse fibroblasts with hen erythrocytes (Poole et al., 1970). The ability of lysolecithin to cause cell fusion has since been confirmed by a number of workers, some of whom have employed the technique to yield viable hybrid cells instead of using Sendai virus for this purpose (Croce, Sawicki, Kritchevsky \& Koprowski, 1971; Croce, Koprowski \& Eagle, 1972; Keay, Weiss, Circulis \& Wildi, 1972).

Lysolecithin in aqueous solution is clearly fusogenic: it is also extremely damaging to biological membranes. Using the concept developed above we may say that, not only are the treated membranes conditioned to facilitate their fusion but their structure is also perturbed so markedly that they disintegrate. Poole et al. (1970) reported that the addition of lipid-free serum albumin to lysolecithin-treated cells arrested the degradative action of lysolecithin on their membranes. In this way, multinucleated erythrocytes were formed that 
appeared to be stable for several hours following fusion, and stabilization by albumin was subsequently adopted by Croce $e t$ al. (1971) to obtain hybrid cells from the fusion of mutant cell lines in culture with the aid of lysolecithin.

Another way of reducing the damaging effects of lysolecithin is to localize its action by confining it to small droplets. This may be done by including the lysophospholipid in the lipid phase of an aqueous emulsion of fat. Since about $10 \%$ of the phospholipid of the nascent fat droplets of cow's milk is lysolecithin and the secretion of milk fat has been suggested to depend on exocytosis (Keenan, Morré, Olson, Yunghans \& Patton, 1970), it seemed possible that the presence of lysolecithin in the nascent fat droplets of milk may be at least partly responsible for membrane fusion involved in the secretion of milk fat by exocytosis. With this in mind, emulsions of fat containing lysolecithin were prepared and tested for fusogenic properties. Fusion following the addition of lysolecithin in an aqueous glyceride-lecithin emulsion to hen erythrocytes was found to be slower than with lysolecithin in aqueous solution, taking 10 to $30 \mathrm{~min}$, and it was accompanied by considerably less damage to the plasma and nuclear membranes. The fused erythrocytes, which usually contained only two or three nuclei, lysed slowly during the $45 \mathrm{~min}$ following fusion, and lysis could be arrested by cooling the fused cells. Further, the plasma membranes of lysed multinucleated cells remained intact at $37^{\circ} \mathrm{C}$ for at least $90 \mathrm{hr}$. Mouse fibroblasthen erythrocyte heterokaryons that were formed by using the emulsion were also more stable than those produced with lysolecithin in solution, but the hybrid cells nevertheless had damaged subcellular organelles. Viable clones of hybrid mouse-hamster fibroblast cells were obtained using the emulsion although, possibly owing to reduced viability of the lysolecithin treated cells, only at twice the frequency of spontaneously produced hybrids.

What of the molecular mechanisms of cell fusion? One suggested way in which membrane fusion may occur involves the presence of a relatively high proportion of globular micelles of lipids or lipoproteins in both of the membranes concerned in the fusion process, interdigitation of the micelles of the two closely apposed membranes then leading to membrane fusion (Lucy, 1969, 1970). A mechanism of this kind appears to be particularly applicable to fusion induced by exogenous Iysolecithin because this lysophospholipid forms globular micelles when it is dispersed in water (Saunders, 1966). It has also been shown that bilayers of lecithin become micellar on the addition of lysolecithin (Bangham \& Horne, 1964; Howell, Fisher, Goodall, Verrinder \& Lucy, 1973). Micelle formation would appear, however, to be an extreme form of structural perturbation in membranes: as a result of this, membranes treated with lysolecithin are very unstable, although it is possible to induce cells to fuse by treatment with other agents, which appear to perturb the organization of the lipids of membranes in a rather different way and with less drastic results (see below). Papahedjopoulos, Poste \& Schaeffer (1973) have reported that phospholipid vesicles, notably those containing phosphatidylserine, can fuse mammalian cells in tissue culture. 
LIPID FLUIDITY IN CELL FUSION

Following the above investigations on lysolecithin, our subsequent studies have shown that more than thirty different fat-soluble substances will cause chicken erythrocytes to fuse into multinucleated cells (Ahkong et al., 1973a). Some of these lipids, e.g. glyceryl monooleate (Cramp \& Lucy, 1974), oleylamine (Pl. 1, Figs 1 to 7) (Bruckdorfer, Cramp, Goodall, Verrinder \& Lucy, 1974), and retinol (K. R. Bruckdorfer, F. G. Cramp and J. A. Lucy, unpublished observations) are also effective in fusing fibroblasts in tissue culture. Glyceryl monooleate in particular has been used to produce hybrid fibroblasts by fusion of hamster and mouse fibroblasts. These hybrid cells, which were obtained up to $\times 32$ more frequently with glyceryl monooleate than in untreated cultures, contained both sets of parental chromosomes and they were subcultured successfully for several months following fusion (Cramp \& Lucy, 1974).

The majority of fusogenic lipid molecules are unsaturated $\left(\mathrm{C}_{16}\right.$ and $\left.\mathrm{C}_{18}\right)$, or medium-chain-length $\left(\mathrm{C}_{10}\right.$ to $\left.\mathrm{C}_{14}\right)$ saturated carboxylic acids or esters of these two classes of fatty acids. The $\mathrm{C}_{6}$ to $\mathrm{C}_{9}, \mathrm{C}_{15}, \mathrm{C}_{16}$ and $\mathrm{C}_{18}$ saturated acids were found not to induce fusion within $4 \mathrm{hr}$ in our test system (Ahkong et al., 1973a). It is interesting that medium-chain-length saturated acids and unsaturated $\mathrm{C}_{16}$ and $\mathrm{C}_{18}$ acids are active as fusogens, since Van Deenen (1969) and his colleagues have demonstrated that these two classes of carboxylic acids behave similarly at the air-water interface, and that they have similar effects on the permeability properties of liposomes.

The fusogens, capric acid $\left(\mathrm{C}_{10}\right)$, oleic and linoleic acids $\left(\mathrm{C}_{18}\right.$, unsaturated acids), but not the fusogenically-inactive saturated acids, palmitic $\left(\mathrm{C}_{16}\right)$ or stearic acid $\left(\mathrm{C}_{18}\right)$, form new undulating structures, rather than globular micelles, when added to lecithin liposomes (Howell et al., 1973). It therefore seems unlikely that these fatty acids cause micelle formation on addition to biological membranes. How then do they cause cells to fuse? The fusogenically active fatty acids have relatively low melting points, so that their insertion into membranes will presumably increase the proportion of hydrocarbon chains in a relatively fluid state. Since fusion induced by glyceryl monooleate is strongly

\section{EXPLANATION OF PLATE 1}

Photomicrographs of mouse $A_{9}$ fibroblasts fixed on coverslips with Zenker's fixative and stained with Harris's haematoxylin. Cells were treated with oleylamine at a concentration of $0.167 \mathrm{mg} / \mathrm{ml}$ in Figs 2 to 7 . (Figs reproduced by permission from Bruckdorfer et al., 1974.)

Fig. 1. Cells incubated in modified Eagle's medium (containing $5 \mathrm{~mm}^{-\mathrm{Ca}^{2}+}$ and 0.8 mM- $\mathrm{Mg}^{2+}$ ), pH $7 \cdot 4$, containing Dextran 60C. $\times 300$.

Frg. 2. Fused cells observed after incubation for $20 \mathrm{~min}$ as in Fig. 1 but with added oleylamine. $\times 300$.

Fig. 3. As for Fig. 2, but at higher power. $\times 700$.

Fig. 4. Cells pretreated with $10 \mathrm{~mm}$-EDTA and then treated with oleylamine in a medium containing no $\mathrm{Ca}^{2+}$ or $\mathbf{M g}^{2+}$ ions; no fusion occurred. $\times 700$.

FIg. 5. Cells treated with oleylamine in the absence of calcium ions but in the presence of $\mathrm{Mg}^{2+}(0.8 \mathrm{mM})$; few fusions occurred. $\times 700$.

Fig. 6. Fused cells observed after treatment with oleylamine in the absence of $\mathrm{Mg}^{2+}$ but in the presence of $\mathrm{Ca}^{2}+(5 \mathrm{~mm}) . \times 700$.

Fra. 7. Cells treated with oleylamine in modified Eagle's medium (containing $5 \mathrm{mM}-\mathrm{Ca}^{2+}$ and $\left.0.8 \mathrm{~mm}-\mathrm{Mg}^{2+}\right)$ with added $\mathrm{La}^{3+}(2 \mathrm{mM})$. Cell fusion was inhibited. $\times 700$. 
PLATE 1
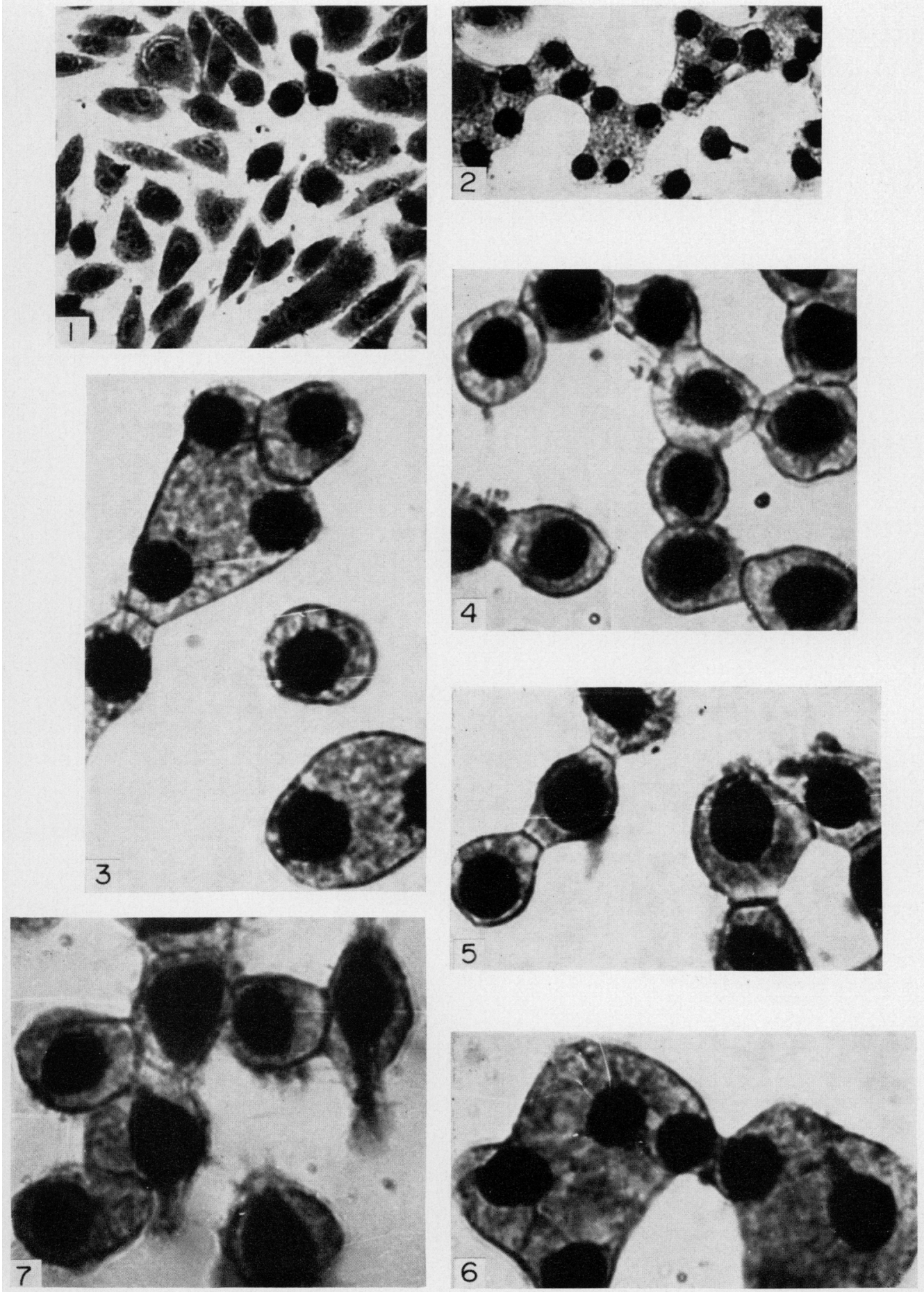

(Facing f) 198) 

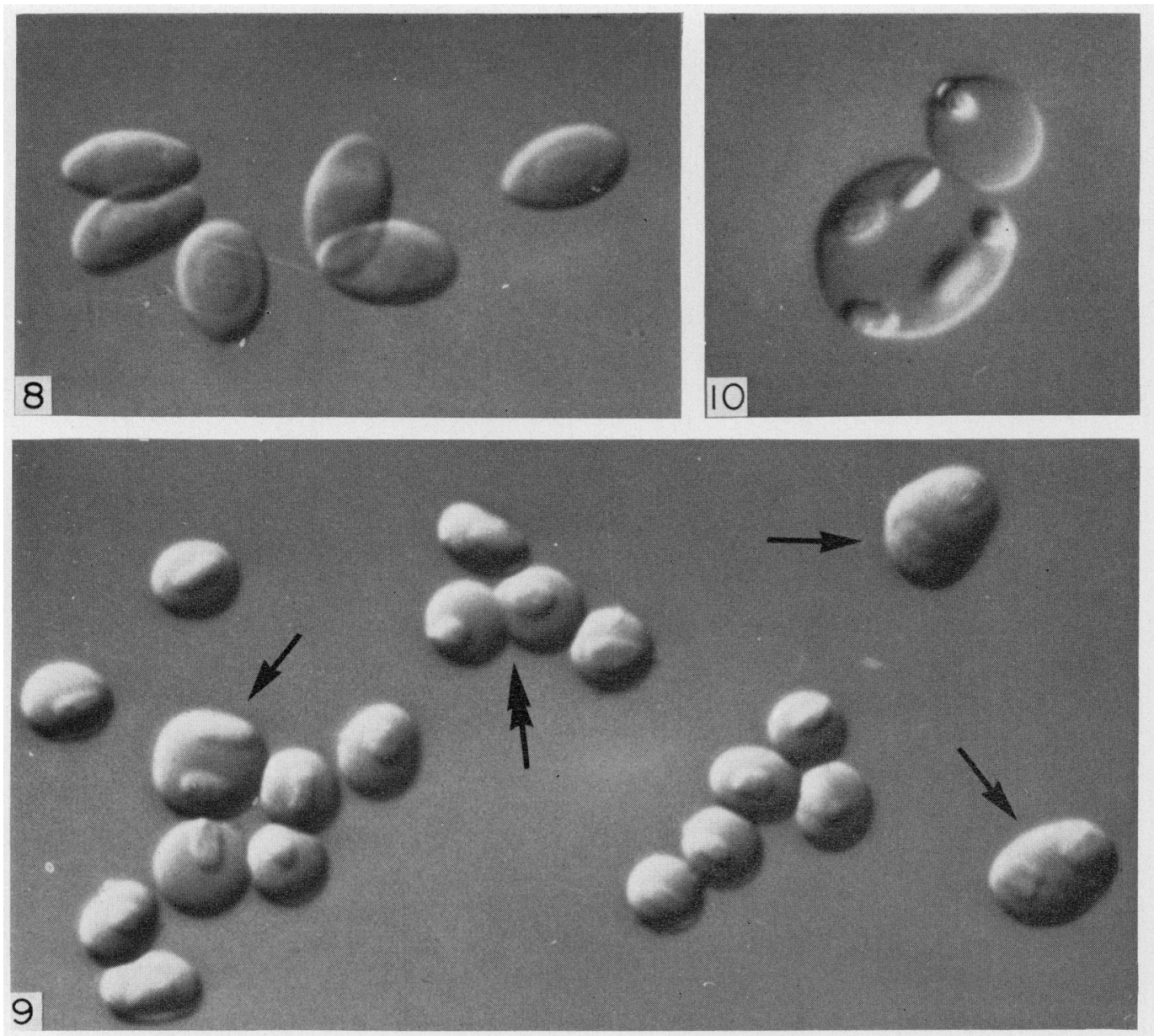

Light micrographe of hen crythoxytes. $x 1200$. These experineme were done in collaboration with $\mathrm{Mr}$ (3. F. Ahkong and 1$) \mathrm{H}$ W. T'ampion.

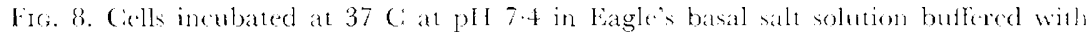
sodium cacodylate (Ahkong at., $1973 a$ ).

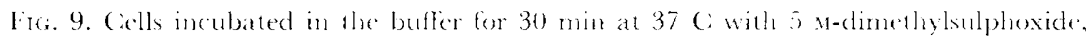
showing the cell adhesion that precedes cell fusion idouble arrow and three binucleate alls (single arrows).

Fu. 10. A multinucleated cell observed after incubation for 90 min as in Fig. 9. Nomarski differential-interference-contrast microscopy. 


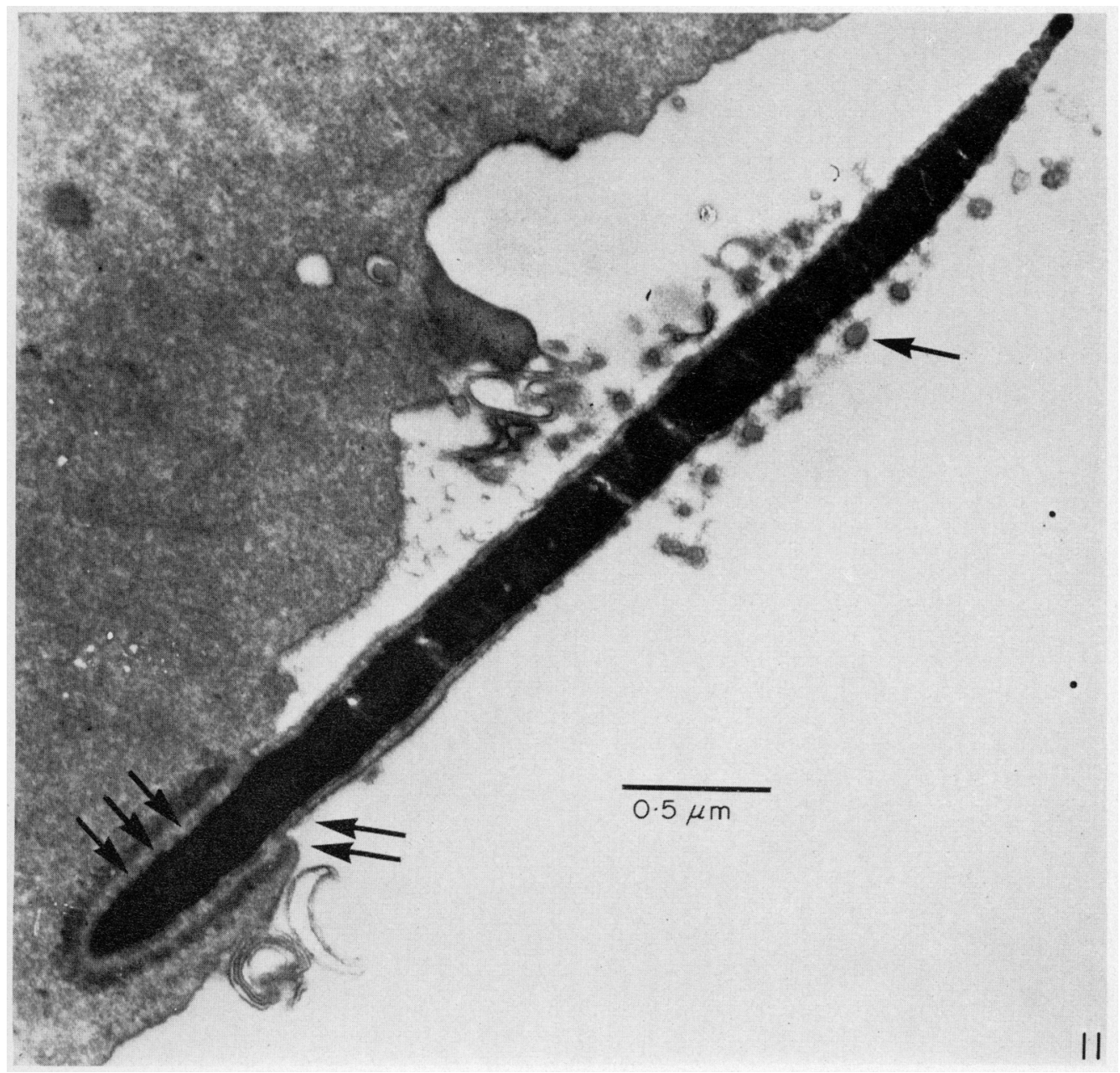

FiG. 11. An electron micrograph of a thin section of a washed ejaculated bull spermatozoon interacting with a hen erythrocyte. 'The two species of cell were incubated together for $2 \mathrm{hr}$ at $37^{\circ} \mathrm{C}$, in buffer at $\mathrm{pH} 5 \cdot 6$, in the presence of glyceryl monooleate $(100 \mu \mathrm{g} / \mathrm{ml})$ (see Ahkong et al., 1973a). Features of membrane structure seen in this micrograph that resemble those occurring in fertilization are discussed in the text. (This work was done in collaboration with Dr G. C. Goeringer and Dr J. I. Howell.) 
temperature-dependent, we consider that an increase in the fluidity of the hydrocarbon interior of membranes provides a second mechanism by which their stability may be reduced sufficiently to permit fusion to proceed (Ahkong et al., 1973b). A number of observations support this hypothesis. First, hen erythrocytes that are treated with progressively smaller quantities of glyceryl monooleate may still be induced to fuse into multinucleated cells by raising the temperature. Secondly, erythrocytes will fuse on the application of heat alone, in the absence of exogenous lipids, when the temperature is raised to $50^{\circ} \mathrm{C}$ (Ahkong et al., 1973b). Also, vesicles of phospholipid that are below

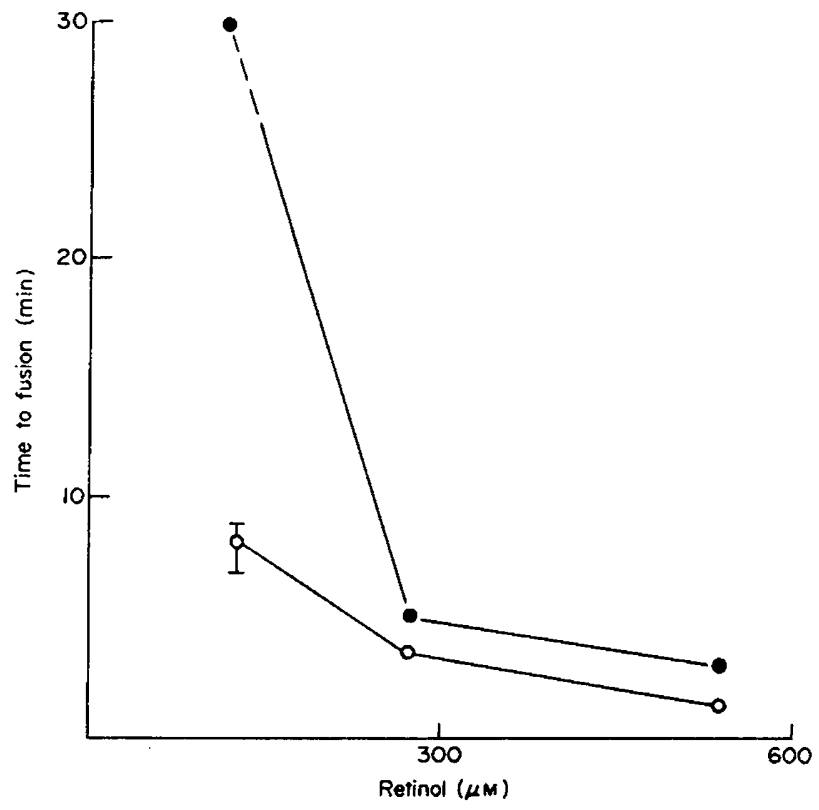

TExT-FIG. 1. The effect of pretreatment of hen erythrocytes with benzyl alcohol before addition of retinol to cause fusion. A suspension of hen erythrocytes $\left(0.1 \mathrm{ml} ; 20 \times 10^{8}\right.$ cells $\mathrm{ml}^{-1}$ ) in Eagle's basal salt solution buffered with sodium cacodylate at pH 5.6 and containing Dextran $60 \mathrm{C}\left(80 \mathrm{mg} \mathrm{mi}^{-1}\right)$ (Ahkong et al., 1973a) was preincubated for 15 $\min$ at $37^{\circ} \mathrm{C}$ either with the buffer alone $(0.15 \mathrm{ml})(\bullet)$ or with benzyl alcohol in buffer $(0.15 \mathrm{ml}, 40 \mathrm{~mm})(\mathrm{O})$. Portions of a dispersion of crystalline, synthetic all-trans retinol (Roche Products Ltd) in buffer were then added, and the final volume brought to $0.65 \mathrm{ml}$ with buffer. The time of incubation after which fusion subsequently commenced was determined. Each point is the mean of two experiments, and the maximum spread of values is illustrated. The experiments were performed with the collaboration of $\mathrm{Dr} D$. Fisher and Mr M. Galloway.

their transition temperature produce less cell fusion than similar numbers of vesicles containing lipids at or above their transition temperature (Papahadjopoulos et al., 1973). In a cell-free system the rate of fusion of phospholipid vesicles (prepared from dimyristoyl lecithin) with one another has been reported to be markedly increased as the temperature is raised to approach the transition temperature of the phospholipid (Prestegard \& Fellmeth, 1974).

Recent investigations made in this laboratory with benzyl alcohol, which is known to increase membrane fluidity (Metcalfe, Seeman \& Burgen, 1968), additionally indicate the importance of the fluidity of membrane lipids in the 
fusion process. Pretreatment of hen erythrocytes with benzyl alcohol, before adding fusogenic quantities of retinol or glyceryl monooleate has been found to result in the cells fusing more rapidly (Text-fig. 1). In related experiments with a concentration of retinol (125 $\mu \mathrm{M})$ that was insufficient in itself to cause the cells to fuse, fusion was observed at progressively shorter time intervals on pretreatment with increasing quantities of benzyl alcohol (Text-fig. 2). Benzyl alcohol $(60 \mathrm{~mm})$ alone was not seen to yield any fused cells after incubation for $30 \mathrm{~min}$ although fusion was observed after $4 \mathrm{hr}$ ( 40 to $60 \mathrm{~mm}$ ).

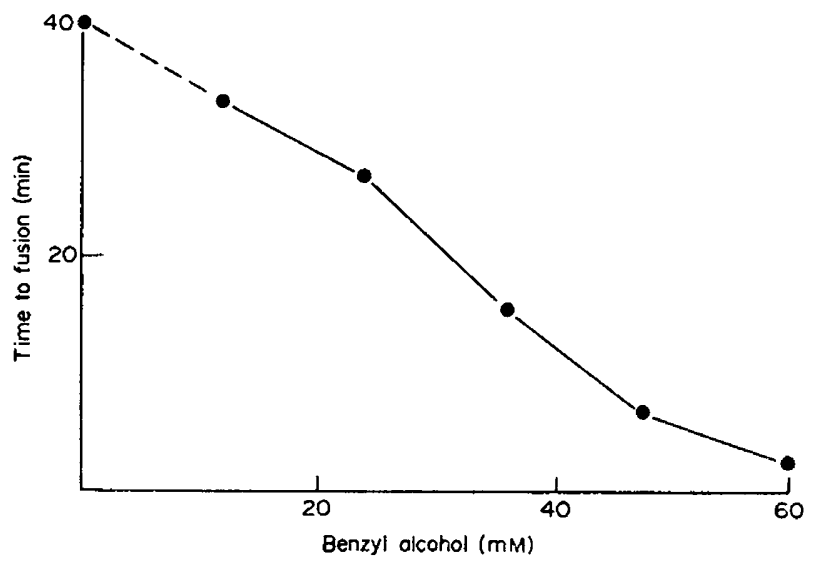

\begin{abstract}
TExT-FIG. 2. The effect of pretreatment with various concentrations of benzyl alcohol on the fusion of hen erythrocytes. A suspension of hen erythrocytes $\left(0.1 \mathrm{ml} ; 20 \times 10^{8}\right.$ cells $\mathrm{ml}^{-1}$ ) in the buffer described in Text-fig. 1 was incubated with increasing concentrations of benzyl alcohol in buffer $(0.15 \mathrm{ml} ; 0$ to $100 \mathrm{mM})$ for $15 \mathrm{~min}$ at $37^{\circ} \mathrm{C}$. Portions of a dispersion of retinol in buffer $(0.4 \mathrm{ml}, 203 \mu \mathrm{M})$ were then added, and the time that elapsed before cell fusion commenced was determined. No fusion was seen during incubation for 40 min with retinol alone or with benzyl alcohol alone. Each result is the mean of three experiments. The experiments were performed with the collaboration of $\mathrm{Dr} \mathrm{D}$. Fisher and $\mathrm{Mr}$ M. Galloway.
\end{abstract}

\title{
THE MOBILITY OF MEMBRANE PROTEINS IN CELL FUSION
}

Poste \& Allison (1973) have proposed that the aggregation of the intrinsic proteins of membranes is an important feature of cell fusion. In our current work we are investigating this idea directly, using the freeze-fracture technique (Zingsheim, 1972) for preparing membrane specimens for electron microscopy to enable us to study movement of the intramembranous particles of membranes during the fusion process. We have also undertaken an indirect test of Poste \& Allison's theory by investigating the effects of dimethylsulphoxide (DMSO) and glycerol on hen erythrocytes in vitro. The intramembranous particles of unfixed $\mathrm{T}$ and $\mathrm{B}$ mouse lymphocytes are reported to aggregate on incubation of the cells at $0^{\circ} \mathrm{C}$ in 25 to $50 \%$ glycerol or DMSO (McIntyre, Gilula \& Karnovsky, 1974). Indirect support is provided for the proposal that the aggregation of intramembranous particles plays a role in membrane fusion, since DMSO and glycerol were found to fuse hen erythrocytes in our usual test system (PI. 2, Figs 8, 9 and 10).

Whether or not enzyme-catalysed reactions are involved in one or more 

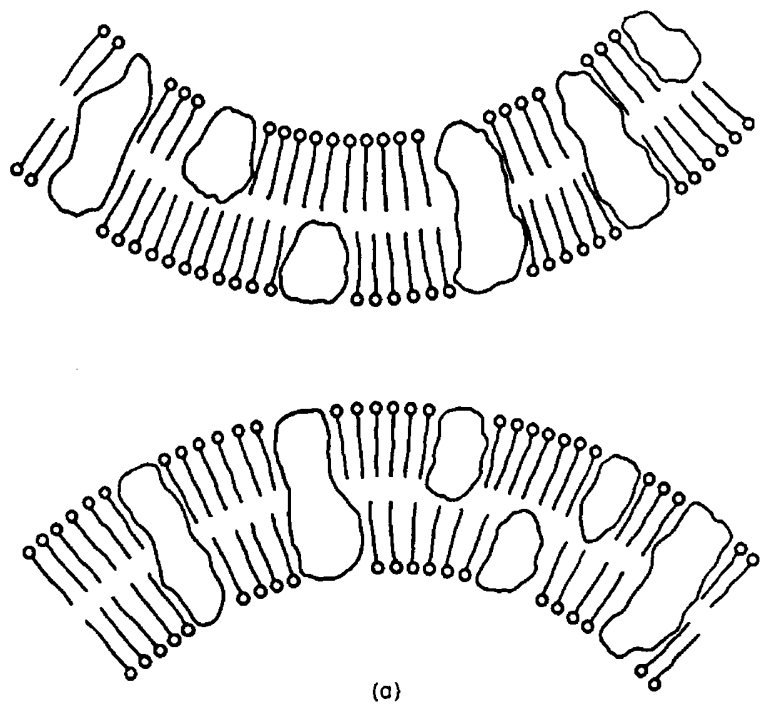

(a)
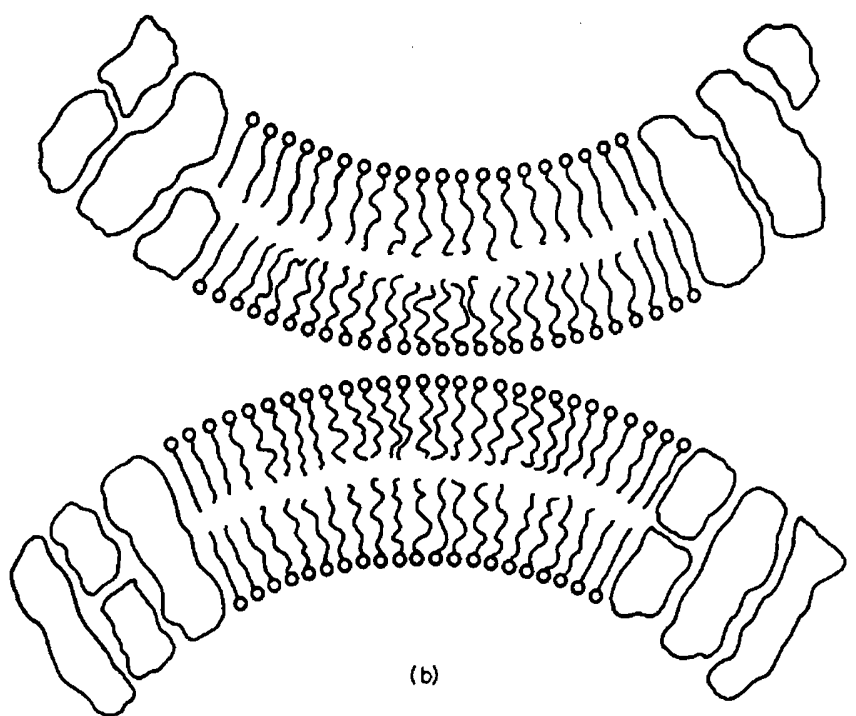

TExT-FIG. 3. Diagrams illustrating suggested possible relationships between the lipid molecules and the intrinsic proteins of biological membranes during membrane fusion. (a) Two membranes that are in close proximity but which do not fuse because the proteins of the membranes are randomly arranged in their respective lipid bilayers; (b) membranes in which fusion may now proceed, by the interaction and intermingling of their lipid molecules, following the emergence of protein-free areas of lipid bilayer consequent upon aggregation of the intrinsic proteins in both membranes. Compared with (a), the lipid molecules of the membranes that are about to fuse have been perturbed; the lipids of (b) are either more fluid (as illustrated) or, in the extreme case, are re-arranged in micellar form (not shown). (Reproduced by permission from Ahkong et al., 1975.) 
stages of the process of chemically-induced cell fusion remains an open question at present. Cell fusion induced by exogenous chemical agents appears, however, to involve at least the following steps. First, a perturbation of the bilayer structure of membrane lipids may occur that increases the fluidity of the lipid region, or in the extreme case results in micelle formation. These changes in the lipid structure of the plasma membrane then allow the aggregation of intramembranous protein/glycoprotein particles to occur. Finally, the interaction and intermixing of the disturbed lipid molecules of closely apposed membranes in regions denuded of intramembranous proteins and glycoproteins may permit adjacent cells to fuse (Text-fig. 3). Comparable mechanisms might apply to fusion occurring between other membrane systems, e.g. in mucocyst secretion by exocytosis in Tetrahymena (Satir, Schooley \& Satir, 1973). In this system fusion occurs between a specific site on the plasma membrane that is bound by a rosette of particles, and a smooth area, devoid of particles, within an annulus on the mucocyst membrane. The two areas of membrane concerned may represent 'conditioned' lipid bilayers that have been denuded of protein particles by aggravation. Considerations of this kind are particularly relevant in the present context in view of recent observations on the fluidity of sperm cell membranes (Johnson, 1975).

\section{FUSION BETWEEN SPERM GELLS AND SOMANTIG CELLS}

Artificially induced fusion between sperm cells and somatic cells provides a model system that may help in the understanding of some aspects of fertilization. Rabbit spermatozoa have been fused with a variety of mammalian somatic cells with the aid of Sendai virus (Brackett, Baranska, Sawicki \& Koprowski, 1971 ; Sawicki \& Koprowski, 1971). Further, Gledhill, Sawicki, Croce \& Koprowski (1972; see also Koprowski \& Croce, 1973) have used lysolecithin to fuse rabbit ejaculated spermatozoa with cultured hamster somatic cells. They reported that disaggregation of sperm nuclear chromatin occurred following fusion, and presumptive evidence was obtained for the synthesis of DNA by the fused chromatin. Bendich, Borenfreund \& Sternberg (1974) have described fusion occurring spontaneously on simple mixing of mouse epididymal spermatozoa and hamster fibroblasts. These investigators also found, using spermatozoa labelled in vivo, that autoradiography showed incorporation of DNA from sperm cells into the nuclei of the recipient cells, indicating release of sperm DNA after mixing.

In this laboratory, experiments have been undertaken with $\mathrm{Dr}$ G. C. Goeringer in which hen erythrocytes have been mixed with washed ejaculated spermatozoa of bulls and incubated with glyceryl monooleate. This treatment resulted in an initial adhesion of the heads of individual spermatozoa to the erythrocytes, effectively immobilizing the sperm cells despite the continued whip-lash movement of their tails. The close adherence of the two cell types was difficult to distinguish from subsequent cell fusion by light microscopy, but some interesting phenomena have been observed with the electron microscope. As shown in Plate 3, the penetration of the nucleus of a sperm cell into an erythrocyte exhibits features that bear a remarkable similarity to the 
ultrastructure of mammalian fertilization (see Barros \& Franklin, 1968). Thus, membrane fusion has apparently occurred between the outer membrane of the acrosome and the plasma membrane of the spermatozoon at its anterior end, giving rise to vesicles that closely resemble those formed in the normal acrosome reaction (single arrow, Pl. 3, Fig. 11). There is also evidence for fusion having occurred between the plasma membranes of the sperm cell and the erythrocyte in the region of the equatorial segment (double arrow, Pl. 3, Fig. 11). The nucleus of the spermatozoon may perhaps be disintegrating in the postnuclear cap region, (triple arrow, Pl. 3, Fig. 11). Finally, in many of the preparations examined, the sperm tail was also seen to be embedded in the cytoplasm of the erythrocyte. We hope that the resemblance between these changes and those observed in fertilization per se indicate that useful information may be obtained on fertilization and cell fusion from model systems of this type. These experiments are being continued and they will be published in more detail elsewhere.

\section{ACKNOWLEDGMENTS}

Work undertaken in this laboratory that is discussed in this contribution was supported by the Medical Research Council. The electron microscope was provided by the Science Research Council.

\section{REFERENCES}

Ahkong, Q.F., Cramp, F. C., Fisher, D., Howell, J. I. \& Lucy, J. A. (1972) Studies on chemically induced cell fusion. 7. Cell Sci. 10, 769-787.

Ahkong, Q.F., Fisher, D., Tampion, W. \& Lucy, J. A. (1973a) The fusion of erythrocytes by fatty acids, esters, retinol and $\alpha$-tocopherol. Biochem. F. 136, 147-155.

Ahrong, Q. F., Fisher, D., Tampion, W. \& Lugy, J. A. (1975) Mechanisms of cell fusion. Nature, Lond. 253, 194-195.

Ahrong, Q.F., Gramp, F. C., Fisher, D., Howell, J. I., Tampion, W., Verrinder, M. \& Lucy, J. A. (1973b) Chemically-induced and thermally-induced cell fusion: lipid-lipid interactions. Nature, Lond. 242, 215-217.

Bangham, A. D. (1963) Physical structure and behaviour of lipids and lipid enzymes. Adv. Lipid Res. 1, 65-104.

Bangham, A. D. (1968) Membrane models with phospholipids. Prog. Biophys. mol. Biol. 18, 29-95.

Bangham, A. D. \& HoRne, R. W. (1964) Negative staining of phospholipids and their structural modification by surface-active agents as observed in the electron microscope. F. molec. Biol. 8, $660-668$.

Barbanti-Brodano, G., Possati, L. \& LaPlaca, M. (1971) Inactivation of polykaryocytogenic and hemolytic activities of Sendai virus by phospholipase B (lysolecithinase). $\mathcal{F}$. Virol. 8, 796-800.

Barros, G. \& FrankLin, L. E. (1968) Behaviour of the gamete membranes during sperm entry into the mammalian egg. F. Cell Biol. 37, c13-c18.

Bendich, A., Borenfreund, E. \& Sternberg, S. S. (1974) Penetration of somatic mammalian cells by sperm. Science, N.Y. 183, 857-859.

BJørnstad, P. (1966) Phospholipase activity in rat liver microsomes studied by the use of endogenous substrates. Biochim. biophys. Acta, 116, 500-510.

Blough, H. A., Gallaher, W. R. \& Weinstein, D. B. (1973) Viral lipids-host cell biosynthetic parameters. In Membrane-Mediated Information, Vol. 1, pp. 183-199. Ed. P. W. Kent. Medical and Technical Publishing Co. Ltd, Lancaster.

Brackett, B. G., Baranska, W., SAWicki, W. \& Koprowski, H. (1971) Uptake of heterologous genome by mammalian spermatozoa and its transfer to ova through fertilization. Proc. natn. Acad. Sci. U.S.A. 68, 353-357.

Bruckdorfer, K. R., Gramp, F. C., Goodall, A. H., Verrinder, M. \& Lucy, J. A. (1974) Fusion of mouse fibroblasts with oleylamine. F. Cell Sci. 15, 185-199. 
Condrea, E. (1974) Membrane-active polypeptides from snake venom: cardiotoxins and haemocytotoxins. Experientia, 30, 121-129.

CRAMP, F. C. \& LUCY, J. A. (1974) Glyceryl monooleate as a fusogen for the formation of heterokaryons and interspecific hybrid cells. Expl Cell Res. 87, 107-110.

Croce, C. M., Koprowski, H. \& EAGLE, H. (1972) Effect of environment $\mathrm{pH}$ on the efficiency of cellular hybridization. Proc. natn. Acad. Sci. U.S.A. 69, 1953-1956.

Groce, C. M., Sawicki, W., Kritchevsky, D. \& Koprowski, H. (1971) Induction of homokaryocyte, heterokaryocyte and hybrid formation by lysolecithin. Expl Cell Res. 67, 427-435.

Danielli, J. F. (1967) The formation, physical stability, and physiological control of paucimolecular membranes. In Formation and Fate of Cell Organelles, pp. 239-253. Ed. K. B. Warren. Academic Press, New York.

Danielli, J. F. \& Davson, H. (1934-35) A contribution to the theory of permeability of thin films. $\mathcal{F}$. cell. comp. Physiol. 5, 495-508.

Diacumakos, E. G. (1973) Microsurgically fused human somatic cell hybrids: analysis and cloning. Proc. natn. Acad. Sci. U.S.A. 70, 3382-3386.

Diacumakos, E. G. \& Tatum, E. L. (1972) Fusion of mammalian somatic cells by microsurgery. Proc. natn. Acad. Sci. U.S.A. 69, 2959-2962.

Dotr, H. M. (1969) Lysosomes and lysosomal enzymes in the reproductive tract. In Lysosomes in Biology and Pathology, Vol. 1, pp. 330-360. Eds. J. T. Dingle and H. B. Fell. North Holland, Amsterdam.

Elsbach, P., Holmes, K. V. \& Choppin, P. W. (1969) Metabolism of lecithin and virus-induced cell fusion. Proc. Soc. exp. Biol. Med. 130, 903-908.

Falke, D., Schtefer, H.-G. \& Stoffed, W. (1967) Lipoid-analysen bei riesenzellbildung durch Herpesvirus hominis. Z. Naturf. 22b, 1360-1362.

Gledhill, B. L., SAwICKI, W., Groce, G. M. \& Koprowskr, H. (1972) DNA synthesis in rabbit spermatozoa after treatment with lysolecithin and fusion with somatic cells. Expl Cell Res. 73, $33-40$.

Goldup, A., Ohkr, S. \& Danielli, J. F. (1970) Black lipid films. In Recent Progress in Surface Science, Vol. 3, pp. 193-260. Eds. J. F. Danielli, A. C. Riddiford and M. D. Rosenberg. Academic Press, New York.

Homma, M. \& Tamagawa, S. (1973) Restoration of the fusion activity of $L$ cell-borne Sendai virus by trypsin. J. gen. Virol. 19, 423-426.

Howell, J. I. \& Lucy, J. A. (1969) Cell fusion induced by lysolecithin. FEBS Letters, 4, 147-150.

Howell, J. I., Fisher, D., Goodall, A. H., VerRinder, M. \& LuCY, J. A. (1973) Interactions of membrane phospholipids with fusogenic lipids. Biochim. biophys. Acta, 332, 1-10.

Johnson, M. H. (1975) The macromolecular organization of membranes and its bearing on events leading up to fertilization. 7. Reprod. Fert. 44, 163-180.

KeAy, L., WEIss, S. A., Circulis, N. \& WiLdI, B. S. (1972) Lysolecithin-induced fusion of fibroblasts. In Vitro, 8, 19-25.

Keenan, T. W., Morré, D., Olson, D. E., Yunghans, W. N. \& Patton, S. (1970) Biochemical and morphological comparison of plasma membrane and milk fat globule membrane from bovine mammary gland. F. Cell Biol. 44, 80-93.

Koprowskr, H. \& CROCE, C. M. (1973) Fusion of somatic and gametic cells with lysolecithin. In Methods in Cell Biology, Vol. 7, pp. 251-260. Ed. D. M. Prescott. Academic Press, New York.

Lucy, J. A. (1969) Lysosomal membranes. In Lysosomes in Biology and Pathology, pp. 313-341. Eds. J. T. Dingle and H. B. Fell. North Holland, Amsterdam.

Lucy, J. A. (1970) The fusion of biological membranes. Nature, Lond. 227, 814-817.

LucY, J. A. (1974) Lipids and membranes. FEBS Letters, 40, s105-s111.

MCINTYRE, J. A., GILULA, N. B. \& KARNovsKY, M. J. (1974) Cryoprotectant-induced redistribution of intramembranous particles in mouse lymphocytes. F. Cell Biol. 60, 192-203.

Metcalfe, J. C., Seeman, P. \& Burgen, A. S. V. (1968) The proton relaxation of benzyl alcohol in erythrocyte membranes. Molec. Pharmac. 4, 87-95.

Mueller, P., Rudin, D. O., Tien, H. T. \& Wescott, W. C. (1964) Formation and properties of bimolecular lipid membranes. Recent Progr. Surface Sci. 1, 379-393.

Mulder, E., VAN DEN Berg, J. W. O. \& Van DeEnen, L. L. M. (1965) Metabolism of red-cell lipids. II. Conversions of lysophosphoglycerides. Biochim. biophys. Acta, 106, 118-127.

Nachbaur, J., Golbeau, A. \& Vignais, P. M. (1972) Distribution of membrane-confined phospholipipases A in the rat hepatocyte. Biochim. biophys. Acta, 274, 426-446.

NewkrRk, J. D. \& WArTe, M. (1971) Identification of a phospholipase $A_{1}$ in plasma membranes of rat liver. Biochim. biophys. Acta, 225, 224-233.

Papahedjopouzos, D. \& Kimelberg, H. K. (1973) Phospholipid vesicles (liposomes) as models for biological membranes: their properties and interactions with cholesterol and proteins. In Progress in Surface Science, Vol. 4, pp. 141-232. Ed. S. G. Davison. Pergamon Press, Oxford. 
Papahedjopoulos, D., Poste, G. \& Schaeffer, B. E. (1973) Fusion of mammalian cells by unilamellar lipid vesicles: influence of lipid surface charge, fluidity and cholesterol. Biochim. biophys. Acta, $323,23-42$.

Pasternak, G. A. \& Micklem, K. J. (1974) The biochemistry of virus-induced cell fusion. Changes in membrane integrity. Biochem. F. 140, 405-411.

Poole, A. R., Howelt, J. I. \& Lucy, J. A. (1970) Lysolecithin and cell fusion. Nature, Lond. 227, 810813.

Poste, G. \& Alurson, A. C. (1971) The membrane fusion reaction: a theory. F. theoret. Biol. 32, 165-184.

Poste, G. \& Alurson, A. C. (1973) Membrane fusion. Biochim. biophys. Acta, 300, 421-465.

Prestegard, J. H. \& Fellmeth, B. (1974) Fusion of dimyristoyllecithin vesicles as studied by proton magnetic resonance spectroscopy. Biochemistry, 13, 1122-1126.

Rahman, Y. E., Verhagen, J. \& Wiel, D. F. M. van Der (1970) Evidence of a membrane-bound phospholipase A in rat liver lysosomes. Biochem. biophys. Res. Commun. 38, 670-677.

Rahman, Y. E., Wright, B. J. \& Gerny, E. A. (1973) Studies on the mechanism of erythrocyte aging and destruction. II. Membrane fragmentation in rat erythrocytes after in vivo treatment with lysophosphatides: scanning electron microscope studies. Mech. Age. Dev. 2, 151-162.

REPorter, M. \& NorRIs, G. (1973) Reversible effects of lysolecithin on fusion of cultured rat muscle cells. Differentiation, 1, 83-95.

SatrR, B., SGHooley, G. \& SATiR, P. (1973) Membrane fusion in a model system. Mucocyst secretion in Tetrahymena. F. Cell Biol. 56, 153-176.

SAUNDERS, L. (1966) Molecular aggregation in aqueous dispersions of phosphatidyl and lysophosphatidyl cholines. Biochim. biophys. Acta, 125, 70-74.

SAwicki, W. \& Koprowski, H. (1971) Fusion of rabbit spermatozoa with somatic cells cultivated in vitro. Expl Cell Res. 66, 145-151.

Shipolini, R. A., Gallewaert, G. L., Cottrell, R. G., Doonan, S., Vernon, G. A. \& Banks, B. E. G. (1971) Phospholipase A from bee venom. Eur. F. Biochem. 20, 459-468.

Singer, S. J. \& Nicolson, G. L. (1972) The fluid mosaic model of the structure of cell membranes. Science, $\mathcal{N}$. Y. 175, 720-731.

Suzuki, Y. \& Marsumoto, M. (1974) Acid phospholipase $A_{1}$ and $A_{2}$ in the cells, and subcellular redistribution of their activities in the cells infected with measles virus. Biochem. biophys. Res. Commun. 57, 505-512.

Van DeEnEn, L. L. M. (1969) Membrane lipids and lipophilic proteins. In The Molecular Basis of Membrane Function, pp. 47-78. Ed. D. C. Tosteston. Prentice-Hall, New Jersey.

Waite, M., Van DeEnen, L. L. M., Ruigrok, T. J. G. \& Elbers, P. F. (1969) Relation of mitochondrial phospholipase A activity to mitochondrial swelling. f. Lipid Res. 10, 599-608.

Zingsheim, H. P. (1972) Membrane structure and electron microscopy. The significance of physical problems and techniques (freeze etching). Biochim. biophys. Acta, 265, 339-366.

ZwaAl, R. F. A., Roelofsen, B. \& Colley, C. M. (1973) Localization of red cell membrane constituents. Biochim. biophys. Acta, 300, 159-182. 